\title{
Effects of liquid pig manure fertilization on the density and species structure of Oribatida (Acari) and green forage yield in a lowland meadow in Poland
}

\author{
BEATA WASIŃSKA-GRACZYK, STANISŁAW SENICZAK and RADOMIR GRACZYK
}

Department of Ecology, University of Technology and Life Sciences in Bydgoszcz, Kordeckiego 20, 85-225 Bydgoszcz; e-mail: beataw77@op.pl

(Received on 3 January 2008; Accepted on 28 December 2009)

\begin{abstract}
The effect of liquid pig manure fertilization, with or without the disinfectant VIT-TRA, on oribatid communities was investigated in a lowland meadow in Poland. The disinfectant was tested at 3 concentrations: $0.50 \%$ (fungicidal), $0.75 \%$ (bactericidal), and $3.00 \%$ (viricidal). Liquid pig manure without the disinfectant increased the green forage yield along with increasing doses of this fertilizer, while addition of disinfectants affected the yield in different ways. Low and medium doses of fertilizer (20 and $40 \mathrm{~m}^{3} \cdot \mathrm{ha}^{-1}$ ) with fungicide slightly decreased the yield, while the high dose $\left(60 \mathrm{~m}^{3} \cdot \mathrm{ha}^{-1}\right)$ usually increased it, as compared to the control. Low and medium doses of liquid pig manure, treated or not with disinfectants, decreased the abundance of oribatid mites. In contrast, the high dose increased their abundance, except for the plot with a high dose of viricide, where they were slightly less abundant than in the control. In the investigated meadow, Liebstadia humerata, Parachipteria bella and Scheloribates laevigatus were abundant, but reacted negatively to low and medium doses of liquid pig manure treated or not with disinfectants, and positively only to the high dose of fertilizer treated with fungicide and bactericide, as compared to the control plot.
\end{abstract}

Keywords: liquid pig manure, disinfectant, permanent grassland, green forage, oribatid mites

\section{INTRODUCTION}

Meadows are an important source of fodder for cattle and other farm animals. To increase the green forage yield, liquid pig manure is often used. Its value for fertilization is intermediate between those of dung and mineral fertilizers. Liquid pig manure is rich in nitrogen $(\mathrm{N})$ and potassium $(\mathrm{K})$, but poor in phosphorus $(\mathrm{P})$. It quickly and strongly stimulates plant growth. It also enriches the soil in organic matter and intensifies the microbial soil life (MORIMOR et al. 2000, Burs et al. 2004). Liquid manure is cheap and lowers the cost of plant production, but in higher concentrations it can be dangerous for the soil and the environment. It contains pathogenic microorganisms, and therefore KLUCZEK (1999) suggested that it should be disinfected before using as a fertilizer. 
The aim of this study was to investigate the effect of various doses of liquid pig manure and various concentrations of a disinfectant on the density and species structure of Oribatida in relation to green forage yield.

\section{MATERIAL AND METHODS}

\section{Study area}

The investigated permanent lowland meadow belongs to the Agricultural Experimental Station in Minikowo (University of Technology and Life Sciences in Bydgoszcz). This hay meadow is situated in the valley of Bydgoszcz Canal (Kanal Bydgoski), about $25 \mathrm{~km}$ from Bydgoszcz. It has been used as a meadow since the late $18^{\text {th }}$ century, but now is used rather extensively. The soil, with a peat layer (about $20 \mathrm{~cm}$ thick), is poor in macronutrients, and is classified as a peat-muck soil (GAPIŃSKI \& MiATKowsKi 1998). The climate of this area is affected both by continental climate from the East and by maritime climate from the West. The yearly mean temperature is $7.5^{\circ} \mathrm{C}$, and precipitation is $491 \mathrm{~mm}$ (ŻARSKI \& DUDEK 2000). The vegetation is composed of herbs and grasses, dominated by reed canary-grass (Phalaris arundinacea L.) and redtop (Agrostis gigantea Roth). Locally dominant are red fescue (Festuca rubra L.), annual bluegrass (Poa annua L.), and rough bluegrass (Poa trivialis L.) (GAPIŃSKi \& MiATKOWSKI 1998).

\section{Experimental design}

In the investigated meadow, 13 plots $(3.5 \mathrm{~m} \times 5.5 \mathrm{~m}$ each) were chosen, with 5.5 $\mathrm{m}$ buffer zones between them. Liquid pig manure was used in doses of $20 \mathrm{~m}^{3} \cdot \mathrm{ha}^{-1}$, i.e. $60 \mathrm{~kg} \mathrm{~N} \cdot \mathrm{ha}^{-1}$ (plots $1,4,7,10$ ), $40 \mathrm{~m}^{3} \cdot \mathrm{ha}^{-1}$, i.e. $120 \mathrm{~kg} \mathrm{~N} \cdot \mathrm{ha}^{-1}$ (plots 2, 5, 8, 11), and $60 \mathrm{~m}^{3} \cdot \mathrm{ha}^{-1}$, i.e. $180 \mathrm{~kg} \mathrm{~N} \cdot \mathrm{ha}^{-1}$ (plots $3,6,9,12$ ). Plots $4-6$ were also treated with $0.50 \%$ VIT-TRA (a disinfectant, which then acted as a fungicide), plots 7-9 with $0.75 \%$ VIT-TRA (as a fungicide and bactericide), and plots $10-12$ with $3.00 \%$ VIT-TRA (as a fungicide, bactericide, and viricide). Plot 0 was a control. The disinfectant VIT-TRA (produced by Laboratoires Ceetal, France), is composed of aqueous solutions of dimethyl ammonium chloride $\left(100 \mathrm{~g} \mathrm{l}^{-1}\right)$, dioxy-12-ethane $\left(32 \mathrm{~g} \mathrm{l}^{-1}\right)$, glutardialdehyde $\left(40 \mathrm{~g} \mathrm{l}^{-1}\right)$, and formaldehyde $\left(31.5 \mathrm{~g} \mathrm{l}^{-1}\right)$.

Soil samples of $17 \mathrm{~cm}^{2}$ in area and $9 \mathrm{~cm}$ deep were taken from each plot in the spring, summer, and autumn of 2006 in 10 replicates (1170 samples in total). The samples were next divided into the lower part of plants $(3-0 \mathrm{~cm})$ and two soil layers $(0-3 \mathrm{~cm})$ and $(3-6 \mathrm{~cm})$. Oribatid mites were extracted in high-gradient Tullgren funnels, preserved, and identified to species level, including the juvenile stages. In total, 7372 oribatid mites were investigated. We compared oribatid species with respect to abundance $\left(A=\right.$ number of individuals per $\left.\mathrm{m}^{2}\right)$ and dominance index $(D=\%$ of the total number of oribatid mites), while oribatid communities with respect to abundance, species number $(S)$ and Shannon index $H^{\prime}$ (ODum 1971). In statistical calculations, we used the HSD Tukey test (one-way ANOVA, Statistica 6). Names of oribatid species follow WeIGMANN (2006). 


\section{RESULTS AND DISCUSSION}

The liquid pig manure without VIT-TRA disinfectants increased the green forage yield along with increasing doses of this fertilizer. This is consistent with the findings of Domek-Chruścicka \& Seniczak (2005) and SokoŁowska \& SeniczaK (2005), who observed effects of liquid cattle and pig manure on green forage yield, respectively. The low dose of liquid pig manure increased the yield by $18.3 \%$, the medium dose by $19 \%$, and the high dose by $32.7 \%$ in relation to the control plot (Table 1 ). The low and medium doses of fertilizer treated with fungicide slightly decreased the yield, while the high dose increased it, as compared to the control plot. All doses of fertilizer treated with fungicide and bactericide increased the green forage yield, except for the plot with the low dose of fertilizer treated with bactericide, where the yield was slightly lower than in the control plot. SoKoŁowsKa \& SENICZAK (2005) and DOMEK-ChruścickA \& SENICZAK (2005) observed no distinct influence of VIT-TRA disinfectants on green forage yield on alternating grassland and arable soil, so the decrease in yield under some combinations of doses of fertilizer and this disinfectant on permanent meadow and peat-muck soil may be connected with the type of soil and needs more investigations. The fertilization caused generally a decrease in the dry matter content of the crop.

Table 1. Green forage yield and dry matter content of fresh forage in the investigated plots

\begin{tabular}{|c|c|c|c|c|c|c|c|c|c|c|c|c|c|}
\hline Plot no. & 0 & 1 & 2 & 3 & 4 & 5 & 6 & 7 & 8 & 9 & 10 & 11 & 12 \\
\hline $\begin{array}{l}\text { VIT-TRA } \\
(\%)\end{array}$ & & 0 & 0 & 0 & 0.50 & 0.50 & 0.50 & 0.75 & 0.75 & 0.75 & 3.00 & 3.00 & 3.00 \\
\hline $\begin{array}{l}\text { Manure } \\
\left(\mathrm{m}^{3} \cdot \mathrm{ha}^{-1}\right)\end{array}$ & 0 & 20 & 40 & 60 & 20 & 40 & 60 & 20 & 40 & 60 & 20 & 40 & 60 \\
\hline $\begin{array}{l}\text { Green forage } \\
\left(10^{3} \mathrm{~kg} \cdot \mathrm{ha}^{-1}\right)\end{array}$ & 7.8 & 9.2 & 9.3 & 10.3 & 7.4 & 6.5 & 10.3 & 7.1 & 10.6 & 10.2 & 8.9 & 9.2 & 11.2 \\
\hline $\begin{array}{l}\text { Dry matter } \\
\text { content }(\%)\end{array}$ & 31.3 & 28.5 & 28.7 & 29.6 & 31.5 & 28.5 & 29.6 & 27.8 & 29.6 & 28.8 & 27.8 & 31.4 & 26.8 \\
\hline
\end{tabular}

Low and medium doses of liquid pig manure, treated or not with disinfectants, decreased the density of Oribatida, while the high dose increased it, except for the plot with the high dose treated with viricide, where density was slightly lower than in the control plot (Table 2). This is consistent with GRACZYK et al. (2009), who investigated the influence of liquid cattle manure with or without disinfectants on oribatid mites.

High densities of oribatid mites were observed in the plot treated with the high dose of fertilizer and fungicide or bactericide. This is consistent with MIKLASZEWSKI (1982), who observed increasing densities of mites under a high dose of N. However, Nakamura (1976), Bolger \& Curry (1980), Bielska (1986) and Trojanowski $\&$ BALUK (1992) noted negative reactions of mites to this $\mathrm{N}$ dose. 
In our study, Liebstadia humerata (Sellnick, 1928), Parachipteria bella (Sellnick, 1928) and Scheloribates laevigatus (C. L. Koch, 1835) were abundant, but reacted negatively to low and medium doses of liquid pig manure treated or not with disinfectants (Table 2). However, the high dose of fertilizer treated with the fungicide and bactericide, increased the density of several species [Liebstadia humerata, L. similis (Michael, 1888), Parachipteria bella, Scheloribates laevigatus], but reduced the density of Galumna obvia (Berlese, 1913) compared to the control plot. Liquid pig manure did not affect the number of species of Oribatida and the Shannon index $H^{\prime}$ for Oribatida, which is consistent with DomeK-Chruścicka \& SEniczak (2005) and SokoŁowska \& Seniczak (2005).

\section{CONCLUSIONS}

1. Liquid pig manure without the disinfectant VIT-TRA increased the green forage yield, along with increasing doses of this fertilizer, while addition of disinfectant affects the yield in different ways. The low and medium doses of fertilizer with a low concentration of VIT-TRA (as a fungicide) slightly decreased the yield, while the high dose usually increased it, as compared to the control plot.

2. Low and medium doses of liquid pig manure treated or not with disinfectants decreased the density of oribatid mites, while the high dose increased it, except for the plot with the high fertilizer dose a high concentration of VIT-TRA (as a viricide), where density was slightly lower than in the control plot.

3. In the investigated meadow, Liebstadia humerata, Parachipteria bella, and Scheloribates laevigatus were abundant. They reacted negatively to low and medium doses of liquid pig manure treated or not with disinfectants, but positively to the high dose of fertilizer treated with low and medium concentrations of VIT-TRA (as a fungicide and bactericide), as compared to the control plot.

\section{REFERENCES}

BIELSKA I. 1986. Communities of moss mites (Acari, Oribatei) of chosen grasslands periodically flooded with liquid manure. Pol. ecol. Stud. 12 (1-2): 163-178.

Bolger T., CurRy J. P. 1980. Effects of cattle slurry on soil arthropods in grassland. Pedobiologia 20: 246-253.

Burs W., Jankowska-Huflejt H., Wróbel B., Zastawny J. 2004. Hay-growing use of green crops. Materials for farmers. MRiRW, Radom (in Polish).

DomeK-Chruścicka K., SENicZAK S. 2005. Effect of swine slurry fertilization on the yield of temporary grassland and the density of some groups of mesofauna. Zesz. Nauk. ATR Bydgoszcz. Zootechnika 35: 37-46 (in Polish).

GAPIŃSKi R., MiatKowski Z. 1998. The analysis after land reclamation of the complex of meadows situated in the Valley of Bydgoszcz Canal, object - RZD Minikowo. Gosp. Pom. GSWG, Prac. Proj., Bydgoszcz (in Polish).

Graczyk R, Seniczak S., Wasińska-Graczyk B. 2009. The effect of cattle liquid manure fertilization on seasonal dynamics of Oribatida (Acari) in a permanent lowland meadow in Poland. Biological Lett. (in press). 


\begin{tabular}{|c|c|c|c|c|c|c|c|c|c|c|c|c|c|c|c|c|c|c|}
\hline$\simeq$ & $\underset{\dot{m}}{\stackrel{8}{0}}$ & 8 & $\stackrel{\dot{\theta}}{\ddot{2}}$ & $\overrightarrow{\mathrm{i}}$ & $\simeq$ & $\ddot{n}$ & $\begin{array}{l}0 \\
\dot{I} \\
\end{array}$ & $\mid \begin{array}{l}\text {. } \\
\text { bi } \\
i \\
i\end{array}$ & $\stackrel{0}{9}$ & $\stackrel{\Rightarrow}{\vec{t}}$ & $\stackrel{\vec{a}}{2}$ & $\begin{array}{l}\infty \\
i\end{array}$ & $\vec{\Xi}$ & $\stackrel{7}{=}$ & $\vec{\Xi}$ & $\stackrel{*}{*}$ & $\stackrel{N}{N}$ & 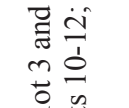 \\
\hline$=$ & $\begin{array}{l}\dot{8} \\
\dot{m}\end{array}$ & ㅇ & $\stackrel{\infty}{\infty}$ & $\stackrel{\sim}{i}$ & $\simeq$ & $\stackrel{\leftrightarrow}{i}$ & $\tilde{a}$ & $\begin{array}{l}\frac{9}{2} \\
0 \\
0\end{array}$ & $\vec{a}$ & $\cong$ & $\stackrel{\infty}{r}$ & $\stackrel{\infty}{-}$ & $\vec{\Delta}$ & $\stackrel{m}{-}:$ & $\stackrel{m}{\infty}$ & $\stackrel{*}{*}$ & $\stackrel{?}{\sim}$ & $\begin{array}{l}\vec{a} 0 \\
0 \\
\ddot{a} \\
\vec{a}\end{array}$ \\
\hline 으 & $\begin{array}{c}8 \\
\dot{m}\end{array}$ & $\stackrel{\sim}{\sim}$ & 市 & $\stackrel{\circ}{i}$ & $=$ & $\ddot{m}$ & $\hat{i}$ & $\stackrel{\check{C}}{-}$ & $\begin{array}{l}m \\
\tilde{n}\end{array}$ & $\begin{array}{l}\bar{\infty} \\
\infty \\
i\end{array}$ & فे & 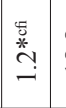 & $\begin{array}{l}\infty \\
\infty \\
\infty\end{array}$ & $\stackrel{m}{\longrightarrow}$ & $\stackrel{\infty}{\infty}$ & $\frac{\vec{*}}{0}$ & $\stackrel{\text { I }}{\text { I }}$ & $\begin{array}{l}0 \frac{0}{0} \\
\frac{0}{2} \\
\frac{0}{2}\end{array}$ \\
\hline$a$ & $\stackrel{n}{a}$ & 8 & 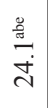 & הี & \pm & 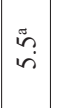 & $\overrightarrow{0}$ & 今̊ & $\ddot{n}$ & 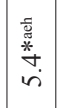 & $\overrightarrow{ \pm}$ & 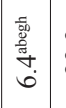 & $\ddot{\sim}$ & $\stackrel{2}{i}$ & $\dot{\vec{g}}$ & 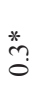 & $\stackrel{0}{-}$ & 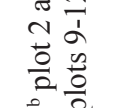 \\
\hline$\infty$ & $\stackrel{n}{i}$ & q & Эิ & $\stackrel{\circ}{i}$ & $\simeq$ & $\stackrel{\sim}{i}$ & $\begin{array}{l}\dot{0} \\
\dot{g}\end{array}$ & $\stackrel{\sim}{\longrightarrow}$ & $\mid \begin{array}{c}0 \\
\infty \\
0\end{array}$ & $\stackrel{\infty}{\stackrel{20}{0}} \stackrel{0}{0}$ & ○. & $\stackrel{+}{-}$ & 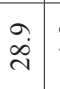 & $\stackrel{m}{\rightarrow}$ & $\begin{array}{l}0 \\
\end{array}$ & $\stackrel{*}{*} \stackrel{0}{o}$ & $\begin{array}{l}0 \\
i\end{array}$ & $\begin{array}{ll}\ddot{i} & \vec{Z} \\
\dot{1} & \Xi \\
0 & \infty\end{array}$ \\
\hline$r$ & $\stackrel{n}{\mathfrak{c}}$ & $\stackrel{\sim}{\sim}$ & กุ & $\vec{i}$ & $\simeq$ & $\stackrel{b}{i}$ & $\begin{array}{l}\infty \\
0 \\
0\end{array}$ & $\stackrel{\circ}{-}$ & $\overrightarrow{\vec{N}}$ & $\stackrel{\vec{i}}{i}$ & 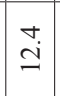 & 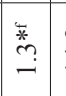 & $\stackrel{m}{ \pm}$ & $\stackrel{9}{-}$ & $\overrightarrow{\dot{\lambda}}$ & $\stackrel{*}{\stackrel{*}{0}}$ & $\stackrel{1}{1}$ & $\begin{array}{l}\frac{0}{2} \frac{0}{2} \\
\frac{2}{0}= \\
\dot{0}\end{array}$ \\
\hline 0 & : & 8 & 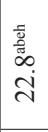 & $\vec{i}$ & $\simeq$ & $\stackrel{m}{a}$ & $\begin{array}{l}0 \\
\dot{i} \\
\stackrel{n}{n}\end{array}$ & $\begin{array}{l}\stackrel{8}{\hat{n}} \\
\dot{m}\end{array}$ & $\stackrel{9}{\beth}$ & $\begin{array}{l}\stackrel{9}{*} \\
\stackrel{*}{*} \\
\text { in }\end{array}$ & $\stackrel{\varrho}{\varrho}$ & 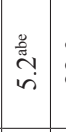 & 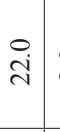 & $\stackrel{a}{a}$ & $\begin{array}{l}0 \\
\stackrel{2}{2}\end{array}$ & $\stackrel{m}{-}$ & 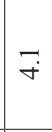 & 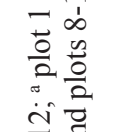 \\
\hline in & in & 우 & $\begin{array}{l}\stackrel{*}{*} \\
\infty \\
\dot{\sigma}\end{array}$ & 9 & $\simeq$ & $\stackrel{\sim}{n}$ & $\vec{i}$ & 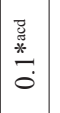 & $\stackrel{N}{N}$ & $\stackrel{m}{-}$ & $\hat{o}$ & 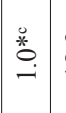 & $\begin{array}{l}\sim \\
\infty \\
\infty\end{array}$ & $\stackrel{m}{\longrightarrow}$ & $\vec{\infty}$ & $\frac{*}{0}$ & $\stackrel{\infty}{0}$ & $\begin{array}{l}\frac{1}{\pi} \\
\frac{\pi}{0} \\
0 \frac{0}{2} \\
2 \frac{0}{2}\end{array}$ \\
\hline$\sigma$ & ?̊ & $\stackrel{\sim}{\sim}$ & $\overrightarrow{0}$ & $\stackrel{\circ}{i}$ & 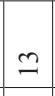 & $\ddot{m}$ & $\vec{n}$ & in & $\stackrel{\sim}{\dot{\delta}}$ & $\stackrel{0}{-}$ & $\underset{\infty}{a}$ & $\stackrel{o}{i}$ & $\stackrel{\sim}{\approx}$ & $\stackrel{n}{\rightarrow}$ & $\vec{n}$ & $\stackrel{*}{*}$ & $\stackrel{0}{0}$ & 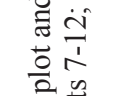 \\
\hline$m$ & 0 & 8 & $\stackrel{i}{\check{I}}$ & $\stackrel{\circ}{i}$ & $\cong$ & $\stackrel{m}{\sim}$ & $\vec{\infty}$ & $\stackrel{+}{-}$ & $\stackrel{n}{0}$ & $\overrightarrow{\mathrm{i}}$ & $\vec{\infty}$ & $\overrightarrow{+}$ & $\stackrel{\sim}{\dot{d}}$ & $\vec{i}$ & $\ddot{\tilde{v}}$ & $\frac{*}{0}$ & $\ddot{0}$ & 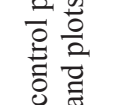 \\
\hline$N$ & 0 & 웅 & กै & $\vec{i}$ & $\simeq$ & $\vec{m}$ & $\hat{\grave{i}}$ & \begin{tabular}{l}
$*$ \\
\multirow{0}{*}{} \\
0 \\
0
\end{tabular} & $\stackrel{\nabla}{\sigma}$ & I & $\stackrel{\infty}{i}$ & $\stackrel{*}{\stackrel{*}{\longrightarrow}}$ & $\begin{array}{l}0 \\
\stackrel{.}{I}\end{array}$ & $\stackrel{9}{\longrightarrow}$ & $\begin{array}{l}n \\
\infty \\
\infty\end{array}$ & $\stackrel{*}{*}$ & $\stackrel{9}{-}$ & $\begin{array}{l}* \\
\ddot{0} \\
\ddot{D}\end{array}$ \\
\hline- & 0 & $\stackrel{\sim}{\sim}$ & ?ु. & $\stackrel{\circ}{i}$ & 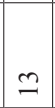 & $\stackrel{\text { I }}{-}$ & $a$ & $\cong$ & nై & $\exists$ & $\stackrel{\vartheta}{\dot{\gamma}}$ & $\stackrel{*}{m}$ & $\stackrel{\vec{\sim}}{\stackrel{\sim}{*}}$ & $\stackrel{\circ}{-}$ & $\overrightarrow{0}$ & $\begin{array}{l}* \\
\infty \\
\infty \\
0\end{array}$ & $\stackrel{\sim}{\sim}$ & 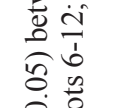 \\
\hline 0 & 0 & 0 & $\ddot{i n}$ & $\vec{i}$ & $\stackrel{2}{-}$ & $\stackrel{\infty}{\infty}$ & $\mid \begin{array}{l}0 \\
\end{array}$ & $\stackrel{\infty}{-}$ & $\begin{array}{l}\stackrel{2}{2} \\
\end{array}$ & $\stackrel{0}{-}$ & $\underset{\infty}{\infty}$ & in & $\overrightarrow{\stackrel{d}{d}}$ & $=$ & $\stackrel{\circ}{=}$ & $\vec{i}$ & $\stackrel{\infty}{\stackrel{\infty}{\perp}}$ & 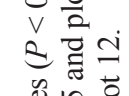 \\
\hline & & & $\nabla$ & $\beth$ & is & $\nabla$ & 0 & $\nabla$ & 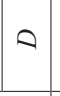 & $\varangle$ & $\theta$ & $\nabla$ & $\theta$ & $\nabla$ & 0 & $\nabla$ & $\theta$ & 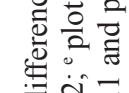 \\
\hline$\stackrel{\dot{0}}{\stackrel{0}{0}}$ & 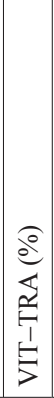 & 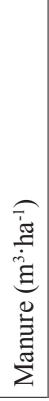 & 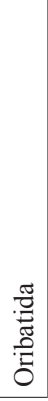 & & & 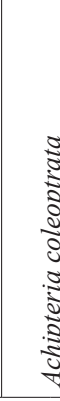 & 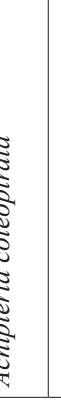 & 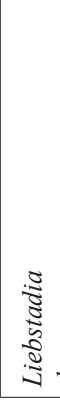 & 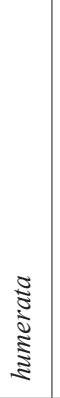 & 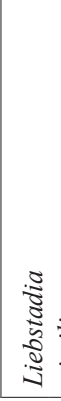 & $\stackrel{\Xi}{\stackrel{\Xi}{\Xi}}$ & 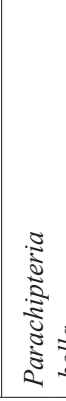 & $\stackrel{\Xi}{\Xi}$ & 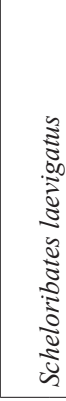 & 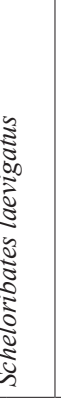 & & 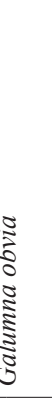 & 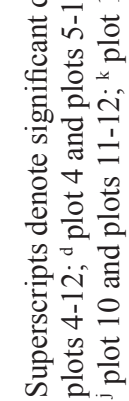 \\
\hline
\end{tabular}


KLuczeK J. P. 1999. Selected problems from environmental protection. Wyd. Ucz. ATR, Bydgoszcz (in Polish).

MiKLASZEWSKI S. 1982. Changes in populations of springtails (Collembola) and mites (Acarina) in light soil under influence of slurry. Zesz. Nauk. AR Wrocław. Rolnictwo 39: 157-165 (in Polish).

Morimor J., Powers W., Sutton A. 2000. Manure characteristics. Manure Management Systems Series. MWPS, Iowa State University.

NAKAmuRa Y. 1976. Decomposition of organic materials and soil fauna in pasture. IV. Disappearance of cow dung and succession of the associated soil microarthropods. Pedobiologia 16: 243-257.

Odum E. P. 1971. Fundaments of ecology. W. B. Saunders Co., Georgia.

SokoŁowska L., Seniczak S. 2005. The effect of cattle liquid manure fertilization on the crop of grassland and on some groups of soil mesofauna. Folia biol. (Kraków) 53 (Suppl.): 133-137.

Trojanowski H., BaluK A. 1992. The effect of nitrogen fertilization on small soil invertebrates - Acarina and Collembola. Rocz. Nauk. Roln. E 22 (1-2): 83-90.

Weigmann G. 2006. Hornmilben (Oribatida). In: Dahl F. (ed.), Tierwelt Deutschlands 76. Teil. GoecKe \& Evers, Keltern: 1-520 pp.

ŻARSKi J., Dudek S., 2000. Results of measurements and meteorological observation in Mochełek. Zakład Agrometeorologii - Wydz. Roln. ATR, Bydgoszcz (in Polish). 